\title{
Empiryczne i ilościowe metody badań wobec naukowego statusu współczesnego językoznawstwa
}

\section{Adam Pawłowski}

Uniwersytet Wrocławski

\section{Trudności w określeniu zakresu nauki o języku ${ }^{1}$}

Dyskusję na temat metodologii językoznawstwa należy rozpocząć od próby określenia statusu i miejsca tej dyscypliny wśród innych nauk. Naukowość lingwistyki jest bowiem kwestią sporną i od lat pozostaje przedmiotem dyskusji, które jak dotąd nie znalazły ostatecznego rozstrzygnięcia. Wynika to z kilku przesłanek, które poniżej wymienię.

1. Językoznawstwo jest jedyną dyscypliną naukową, w której przedmiot badań i narzędzie opisu są tożs a me. Jednak języki naturalne, użyte w funkcji narzędziowej, są wieloznaczne, redundantne, a ich struktura jest niespójna. Nie pozwala to na konstruowanie dyskursu naukowego, który w swojej formie i treści byłby jednoznaczny, spójny, niesprzeczny i możliwie prosty. W praktyce dyskursu językoznawczego oba poziomy — narzędziowy i przedmiotowy - przenikają się bowiem wzajemnie, oddalając językoznawstwo od standardów wyznaczonych przez

1 Polskojęzyczna literatura przedmiotu poświęcona problemom metodologii badań lingwistycznych nie przedstawia się zbyt okazale. Na najwyższym poziomie ogólności znajdują się prace naukoznawcze, które problemom epistemologii i metodologii badań poświęcają wiele miejsca, jednak poziom ich ogólności bardzo utrudnia praktyczne zastosowania (Pieter, 1967; Pawłowski, 1977 i 1978; Kamiński, 1998; Krajewski, 1998; Hajduk, 2001). Bardziej przydatne w badaniach lingwistycznych mogą okazać się prace z zakresu metodologii nauk społecznych, ponieważ zawierają one opisy technik ankietowych, statystyki i pewnych szczegółowych aspektów badań, na przykład metody reprezentacyjnej (Steczkowski, 1995; Gruszczyński, 2001; Nowak, 2007). Kwestiom metodologii badań językoznawczych poświęcono kilka zbiorów artykułów (Stalmaszczyk, 2006, 2008; Pogonowski, Zgółka, 1996), pewną liczbę prac z zakresu lingwistyki kwantytatywnej i korpusowej (Sambor, 1972; Hammerl, Sambor, 1990; Pawłowski, 2001; Lewandowska-Tomaszczyk, 2005), prace z zakresu analizy zawartości tekstów (Pamuła, 1996; Pisarek, 1983) oraz wiele tekstów dotyczących szczegółowych zastosowań (por. Czekanowski, 1913; Kopczyńska, Pszczołowska, 1959; Bajor, 1970; Cockiewicz, Śliwiński, 1982; Bartmiński, 1988; Dębowski, 2001). 
języki opisu stosowane w naukach formalnych i przyrodniczych, które można traktować jako wzorzec poprawności metodologicznej w tym względzie ${ }^{2}$.

2. Konsekwencją psychologistycznego podejścia do języka jest tożs a mość podmiotu i przedmiotu poznania. Człowiek-homo sapiens i homo loquens w jednej osobie - staje się więc jednocześnie poznającym i poznawanym. Skutkiem tego jest między innymi krytyka metod dedukcyjnych, określanych jako tzw. lingwistyka fotelowa (Svartvik, 1992), przerost ambicji radykalnego empiryzmu, który z lingwistyki korpusowej, kontynuującej najlepsze tradycje badań materiałowych, uczynił oręż walki z generatywizmem oraz sporny status metody introspekcyjnej ${ }^{3}$.

3. Kolejną ważną przesłanką w debacie metodologicznej jest fakt, iż język jest zjawiskiem leżącym na pograniczu kultury i natury, a co za tym idzie, językoznawstwo jest jedyną ukształtowaną dziedziną wiedzy, która niejako z definicji usytuowana jest na pograniczu humanistyki i nauk przyrodniczych — także w zakresie metodologii (por. Kamiński, 1998, 293-300).

4. Język jako przedmiot bezpośredniej obserwacji dostępny jest naukowcom przez tysiące różnych, ewoluujących w czasie i często w praktyce niedostępnych manifestacji, określanych jako etnolekty. Tylko niektóre z nich posiadają pismo, wiele nigdy nie zostało opisanych, a fakt uznania konkretnego etnolektu za język opiera się raczej na przesłankach politycznych, a nie lingwistycznych.

5. Ostatnia trudność w określeniu statusu językoznawstwa dotyczy natury samego przedmiotu badawczego. Język jest bytem tak złożonym, że każda próba jego jednoznacznego, systematycznego i uporządkowanego opisu zawsze prowadzi do wyeksponowania pewnych jego aspektów, a zarazem pominięcia innych. Można więc powiedzieć, że redukcjo n i z m o z naw c z y jest wpisany w naukowe badanie języka, o ile tylko jest ono zgodne z jakąś teorią. Próba c ałości o w e go opisu języka musi z kolei prowadzić do głębokiego eklektyzmu metodologicznego i w mojej opinii graniczy z utopią. Opisana tu złożoność przedmiotu badań widoczna jest w definiowaniu i opisywaniu języka z różnych punktów widzenia, a zarazem w ramach różnych orientacji badawczych. ${ }^{4}$ Za najbardziej wyraziste uznać można następujące podejścia ${ }^{5}$ :

2 Ograniczenie to można przezwyciężyć, stosując za Alfredem Tarskim rozróżnienie języka przedmiotowego i metajęzyka, czyli języka narzędziowego wyższego poziomu. Jednak w literaturze lingwistycznej, gdzie sztuczne notacje nigdy się nie przyjęły, granica między językiem użytym narzędziowo i przedmiotowo jest przeważnie zatarta.

3 Doświadczenie pokazuje, iż rasowy badacz prędzej pożyczy koledze po fachu swoją szczoteczkę do zębów niż przestanie ufać swojej intuicji.

4 Można dodać, że wieloaspektowy charakter języka prowadzi do sytuacji, w której różnobrzmiące sądy na temat języka mogą być jednocześnie prawdziwe i prowadzić do zaskakujących implikacji. Implikacją jednoczesnej prawdziwości sądów: „Każdy język jest systemem”, „Każdy język jest wytworem myśli”, „Każdy język jest zbiorem zdań”, „Każdy język jest rozwijającym się organizmem”, „Każdy język jest zbiorem reguł generujących zdania” mogą być sądy „Zbiór zdań jest zbiorem reguł te zdania generujących”, „Zbiór reguł generujących zdania jest rozwijającym się organizmem” itd.

5 Omówione tu podejścia badawcze reprezentowane są przez obszerną literaturę przedmiotu, której nie cytuję, odsyłając zainteresowanych do powszechnie dostępnych baz bibliograficznych (wyjątkiem jest lingwistyka kwantytatywna i statystyczna, a to z uwagi na temat przewodni artykułu). O heteronomicznym podejściu w polskim językoznawstwie pisali między innymi Antoni Furdal (1990) i Zdzisław Wąsik (1996). 


\section{Psychologistyczne (psycholingwistyczne)}

Język traktowany jest jako względnie autonomiczny byt psychiczny, stanowiący narzędzie myślenia, komunikacji i ekspresji uczuć. Preferowanymi metodami są introspekcja, badania ankietowe i/lub eksperymentalne. Aspekty pragmatyczne i społeczne, a także funkcje komunikacyjno-perswazyjne tekstów, traktowane są jako drugorzędne. Język jest ujmowany w perspektywie indywidualnej, a nie społecznej (przedmiotem opisu są idiolekty, a nie odmiany wspólne i/lub język standardowy).

\section{Neurofizjologiczne}

W tym wypadku język jest traktowany jako byt psychiczny nierozerwalnie powiązany ze swoim fizjologicznym nośnikiem, czyli mózgiem, wobec którego pełni funkcję swoistego biologicznego oprogramowania. Jego badanie wymaga stosowania metod eksperymentalnych, opartych na technikach bezinwazyjnego obrazowania stanów mózgu za pomocą rezonansu magnetycznego lub pozytonowej tomografii emisyjnej (tzw. PET).

\section{Socjologiczne}

Przyjmuje się, że język, zarówno w ujęciu systemowym, jak i pragmatycznym, jest silnie powiązany z podstawowymi zmiennymi socjologicznymi, takimi jak wiek, płeć, wykształcenie, status społeczny, pochodzenie jego użytkowników. Zakłada się, że między charakterystykami socjologicznymi i językowymi zachodzą w praktyce komunikacyjnej złożone związki, których podstawą jest ich wzajemny izomorfizm (oznacza to, że rozczłonkowanie socjologiczne zostaje powielone $\mathrm{w}$ formie rozczłonkowania językowego). Podstawową metodą badawczą jest ankieta wzbogacona o techniki statystyczne.

\section{Antropologiczne}

W tej perspektywie język traktowany jest jako wytwór, spoiwo i centralny składnik kultury. Przedmiotem badań jest językowy obraz świata (JOS), stanowiący skarbnicę potocznej wiedzy i doświadczenia każdej wspólnoty ludzkiej. Do podstawowych technik badawczych należą analiza zawartości tekstów konkretnej kultury oraz metody ankietowe, służące między innymi do tworzenia profili leksykalnych, określanych również jako dyferencjał semantyczny (Osgood et al., 1957; Osgood, 1964; Snider, Osgood, 1969). Dyskusyjną kwestią jest zachowanie neutralności badacza w stosunku do opisywanych treści. Według koncepcji kojarzonych z behawioryzmem tylko badacz, który zachowuje dystans do opisywanego języka i kultury, jest w stanie stworzyć ich poznawczo wartościowy opis. ${ }^{6} \mathrm{Z}$ kolei podejście przedstawicieli lubelskiej szkoły antropologicznej zakłada, iż zanurzenie badacza w opisywanej kulturze nie jest żadną przeszkodą w procesie tworzenia wiedzy obiektywnej na temat tego, co w swojej genezie i funkcjonowaniu jest subiektywizmem (na przykład stereotypy językowe jako preferowany przedmiot refleksji nad językowym obrazem świata) (Bartmiński, 2004).

\section{Semiotyczne}

Podstawowym założeniem podejścia semiotycznego do języka jest teza o jego prymarnie znakowym charakterze. Język w tym ujęciu jest najbardziej wszechstronnym i uni-

6 Przykładem takiego „spojrzenia z zewnątrz” są prace antropolingwistyczne badaczy języków etnicznych (między innymi pierwszych strukturalistów amerykańskich — Edwarda Sapira i Franza Boasa), a także funkcjonalisty Bronisława Malinowskiego (Szymura, 1985). 
wersalnym system znakowym, podlegającym jednak regułom obowiązującym w innych systemach znakowych i częściowo z nimi kompatybilnym (Wąsik, 1987). W podejściu semiotycznym dominuje więc aspekt semantyczno-strukturalny przekazu, natomiast kwestie specyficznie językowe, a więc fonetyka, morfologia i składnia, mają drugorzędne znaczenie. Metody semiotyki mają charakter interdyscyplinarny.

\section{Komunikacyjne}

Podejście komunikacyjne opiera się na założeniu, iż podstawową funkcją języka jest komunikacja, tak interpersonalna, jak i masowa. Procesy kulturotwórcze i wytwory kultury są w takim ujęciu wtórne w stosunku do komunikacji. Podejście to jest jednak pod wieloma względami niespójne z uwagi na istotne różnice między zakresem, funkcją i ujęciami teoretycznymi komunikacji interpersonalnej oraz masowej. Metody badań komunikacjonistycznych nie różnią się co do założeń od tych, które stosuje się w socjolingwistyce i psycholingwistyce. Warto jednak podkreślić, że szczególnie przydatne w badaniu komunikacji masowej jest podejście korpusowe i ilościowe, ponieważ jego przedmiotem są obszerne zbiory tekstów, określane jako dyskursy (na przykład dyskursy polityczne i społeczne). Zbiory takie, liczące setki tysięcy lub miliony słów tekstowych, są zbyt obszerne, aby pracować z nimi metodami tradycyjnymi. W badaniach komunikacjonistycznych możliwe jest jednak również korzystanie z dorobku filologii, na przykład z metod eksplikacji, filiacji bądź egzegezy tekstów, stosowanej tradycyjnie w analizie utworów literackich.

\section{Dydaktyczne}

W tym ujęciu język jest przedmiotem nauczania w instytucjonalnych systemach edukacji. Aspekt ten ma szczególne znaczenie w Europie, gdzie nauka języków obcych jest zjawiskiem powszechnym, a języki narodowe są wyznacznikami tożsamości wspólnotowej. $\mathrm{Z}$ metodologicznego punktu widzenia przydatne są tu metody korpusowe (analizy błędów oraz dostarczanie reprezentatywnych próbek „prawdziwego” języka) oraz psycholingwistyczne (uwarunkowania indywidualnego procesu przyswajania języka).

\section{Filozoficzne}

Język pojawia się jako przedmiot refleksji filozoficznej w ontologii, epistemologii, aksjologii i estetyce. Z punktu widzenia ontologii język jest bytem, którego złożona, abstrakcyjno-konkretna natura stanowi przedmiot opisu. W epistemologii język jest traktowany jako jedno z narzędzi poznania. W kontekście aksjologii język, a dokładniej językowy obraz świata, jest punktem odniesienia dla procesów wartościowania. $\mathrm{Z}$ punktu widzenia estetyki język tekstu artystycznego, podobnie jak dzieło sztuki, podlega analizie jako źródło doznań estetycznych.

\section{Retoryczno-perswazyjne}

W tym ujęciu język może być definiowany jako narzędzie kształtowania postaw, poglądów i działań innych ludzi. Podejście to przyjmowane jest powszechnie w studiach komunikacjonistycznych z obszaru politologii (perswazyjne ukształtowanie tekstów i/lub dyskursów politycznych), ekonomii (teoria i praktyka reklamy) oraz praso- i medioznawstwa. Metodologia badań odwołuje się do licznych teorii retoryki i reklamy, jednak z uwagi na gwałtowny przyrost liczby tekstów i masowy charakter komunikacji elektronicznej, wymaga stosowania narzędzi korpusowych i ilościowych. 


\section{Matematyczno-statystyczne i inżynieryjne}

W tym ujęciu język występuje w dwojakiej roli. Jest przedmiotem opisu dokonywanego za pomocą narzędzi matematycznych (liczbowe charakterystyki jednostek językowych, tekstów, odmian, stylów itd. oraz funkcyjne reprezentacje wzajemnych relacji tych elementów). Bazą teoretyczną takiego podejścia jest lingwistyka kwantytatywna (Sambor, 1972; Muller, 1973; 1977; Butler, 1985; Woods et al., 1986; Zgółkowa, 1987; Hammerl, Sambor, 1990; Altmann, 1995). Język jest jednak również obiektem modelowania, które służyć ma pełnemu odtworzeniu mechanizmów kompetencji językowej (w rozumieniu generatywistycznym) za pomocą programów komputerowych (Manning, Schütze, 2000). Na obecnym etapie badań takiej symulacji poddają się tylko niektóre fragmenty kompetencji. Możliwe jest na przykład tworzenie automatycznych zbiorów słów kojarzonych z sobą pod jakimś względem (ontologie, słowosieci — Piasecki et al., 2009), rozpoznawanie struktury morfosyntaktycznej zdań (Hajnicz, Kupść, 2001), rozpoznawanie i transkrypcja ciągu mowy. W tym ujęciu język naturalny traktowany jest też jako rzeczywisty odpowiednik bądź prototyp języków formalnych. Aspekty pragmatyczne, komunikacyjne i społeczne odgrywają w algorytmach modelowania kompetencji ciągle jeszcze niewielką rolę. Przy analizie danych korpusowych i automatycznym przetwarzaniu zdań wykorzystuje się intensywnie metody matematyczne (między innymi statystyka z rachunkiem prawdopodobieństwa, algebra, analiza matematyczna, teoria automatów, teoria informacji). Podejście to jako jedyne praktycznie odeszło już od ręcznej obróbki tekstu. Z wyjątkiem interpretacji wyników wszystkie czynności wykonywane są przez komputer.

Do powyższej listy trudności dołączyć można kontrast między poznaniem potocznym i naukowym. To pierwsze ma charakter utylitarystyczny, wartościujący, jest niespójne, nacechowane subiektywizmem, ale może spełniać funkcje regulatora procesów adaptacyjnych człowieka. Poznanie naukowe ma cel teoretyczny, służy budowaniu praw i teorii dotyczących pewnej dziedziny wiedzy. Ma być uniwersalne, a więc niezależne od kontekstu czasoprzestrzennego i społecznego. Powinno także przekładać się na praktyczne zastosowania. Opozycja powyższa jest silnie powiązana z poziomem wiedzy o języku w konkretnym społeczeństwie, co wynika z tego, iż wszyscy ludzie potrafią posługiwać się mową, a w krajach o minimalnym choćby stopniu skolaryzacji posiadają też wiadomości z zakresu gramatyki. Przejawem konfliktu wiedzy potocznej i naukowej jest istnienie długiej listy fałszywych - w sensie naukowym - przekonań na temat języka, mówiących na przykład o istnieniu języków łatwych i trudnych, ładnych i brzydkich, genetycznie czystych i mieszanych (a więc zdegenerowanych) itd.

Jak z powyższego widać, naukowe podejścia do języka różnią się od siebie w istotny sposób, chociaż każde z nich jest w ramach swojej teorii uzasadnione. Każde opiera się na nieco innej definicji języka, dopuszcza także korzystanie z różnych metod badawczych.

\section{Eklektyzm metodologiczny czy podejście fasetowe?}

Jedną z wpływowych, co nie znaczy, że słusznych opinii na temat niejednoznacznego statusu nauk społecznych, a więc pośrednio także językoznawstwa, wyraził fizyk 
i filozof nauki Thomas S. Kuhn. Zauważył on, iż „Pozostaje sprawą otwartą, czy którakolwiek z dyscyplin nauk społecznych w ogóle osiągnęła już jakiś paradygmat. Historia ukazuje, że droga do osiągnięcia takiej jednomyślności w badaniach jest niezwykle uciążliwa” (Kuhn, 1968, 31). W dalszej części swojego wywodu Kuhn mówi o przypadkowym gromadzeniu faktów przez uczonych stadium przedparadygmatycznego, którzy nie kierują się przy tym żadną teorią. Poglądy Kuhna były w latach sześćdziesiątych i siedemdziesiątych XX wieku tematem wielu dyskusji w polskiej lingwistyce. Tu chciałbym przytoczyć opinię Z. Wąsika dotyczącą tej kwestii:

To nam z kolei wskazuje, że przedtem musiał istnieć również pewien okres przedparadygmatyczny. Okres ten charakteryzuje się według Kuhna przede wszystkim brakiem wspólnej ramy łączącej uczonych. Uczeni tracą czas i energię na bezowocne dyskusje na temat podstaw dyscypliny i na przypadkowe gromadzenie danych. (Wąsik, 1987, 28)

Z perspektywy kilkudziesięciu lat należy stwierdzić, że naukoznawcze rozważania Kuhna straciły atrakcyjność, ukazując przy okazji swoją merytoryczną miałkość. Najsłabszym ogniwem jego koncepcji jest pojęcie paradygmatu, które swój sukces zawdzięcza tak ogólnikowej definicji, że każdy może podstawić pod nią nieco inne treści, nadając przy okazji nie zawsze jasnym wypowiedziom walor naukowości: „[...] powszechnie (jak poznajemy, że coś jest powszechne? - A. P.) uznawane (przez kogo? - A. P.) osiągnięcia naukowe (jak odróżnić wytwory nauki, które są osiągnięciami od tych, które nimi nie są? - A. P.), które w pewnym czasie (a nie miejscu? - A. P.) dostarczają społeczności uczonych modelowych problemów i rozwiązań (kto decyduje i na jakiej podstawie, że problem jest lub nie 'modelowy'? - A. P.).” (Kuhn, 1968, 12). Ponadto pojęcie paradygmatu niesłusznie stygmatyzuje każdą dyscyplinę nauki jako słabo rozwiniętą (przed pojawieniem się pierwszego paradygmatu) lub dojrzałą (po jego stworzeniu). Z założeń teorii Kuhna wynika też, iż tzw. okres przedparadygmatyczny jest nienaukowy, a każdy kolejny paradygmat obala poprzedni jako mniej efektywny pod względem poznawczym. Tak jest, jego zdaniem, w naukach przyrodniczych. ${ }^{7}$ Nauki społeczne (a więc lingwistyka), o ile miałyby znaleźć się w tym dostojnym gronie, powinny więc podążyć tą samą drogą.

Problem polega jednak na tym, że w rozumowanie Kuhna wpisana jest głęboko oświeceniowa idea postępu, uzasadniona przez niego prymatem historii i wzbogacona elementami biologizmu (sekwencja cyklu nauki, na którą składają się powstanie, rozwój i upadek paradygmatu). Pierwsze zdanie Struktury rewolucji naukowych brzmi następująco: „Wiedza historyczna, jeśli nie traktować jej wyłącznie jako skład-

7 Dyskusja nad słabościami koncepcji Kuhna wymagałaby osobnej rozprawy, wychodzącej zupełnie poza obszar lingwistyki. W tym miejscu, bez specjalnego przygotowania, można jednak wytknąć autorowi fałszywe założenie, że nauka ujęta całościowo zajmuje się niezmiennie tymi samymi problemami, ulepszając jedynie swoje „paradygmaty”, które obala od czasu do czasu w drodze rewolucji. Prawda to tylko częściowa, ponieważ odkrywane lub definiowane są nowe obiekty badań, których istnienia nie przeczuwano, pojawiają się więc zupełnie nowe pytania badawcze, do których stare teorie nie mają zastosowania. Mówiąc natomiast o naukach społecznych, wypada przyznać, że Kuhn jako fizyk nie rozumie ich specyfiki. Można to spuentować stwierdzeniem, iż adekwatny do treści tytuł jego pracy brzmiałby Struktura rewolucji naukowych $w$ fizyce i $w$ przyrodoznawstwie. Można też zacytować fragment przedmowy do Struktury rewolucji naukowych, w którym autor przyznaje wprost, iż historii nauki nigdy nie studiował systematycznie (Kuhn, 1968, 11). 
nicy chronologicznie uporządkowanych anegdot, zmienić może w zasadniczy sposób obraz nauki, jaki mamy w naszej myśli” (Kuhn, 1968, 15). ${ }^{8}$ Pomijając milczeniem trywialne podejście do historiografii (historia jako zbiór anegdot), należy zauważyć, że $\mathrm{w}$ lingwistyce, a więc jednej z nauk społecznych, nie może być mowy o tak rozumianym postępie. Język jest bowiem tworem skomplikowanym, ujmowanym w różnych perspektywach, których przegląd, zapewne niekompletny, podałem we wcześniejszej części artykułu. Wszystkie perspektywy są poznawczo wartościowe, a wynikające z nich uogólnienia nie zaprzeczają sobie nawzajem, lecz uzupełniają się. Przejście od orientacji komunikacjonistycznej do neurolingwistycznej (lub na odwrót), od lingwistyki historyczno-porównawczej do generatywizmu (lub na odwrót) nie może być $\mathrm{w}$ żadnym sensie rozpatrywane $\mathrm{w}$ kategoriach postępu, przewrotu lub regresu.

Podejście takie określać można jako synkretyczne, ale znacznie lepiej jest mówić o fas e tow y m ujęciu języka. Nazwa fa s e ta została zaczerpnięta z terminologii jubilerskiej. Oznacza jedno płaskie cięcie bryły kryształu (klasyczny szlif brylantowy składa się z 72 faset). Brylant widziany z różnych perspektyw inaczej załamuje promienie świetlne, przez co zmienia swój wygląd, nie tracąc jednak zwartości jako jednorodny przedmiot. Analogia jest więc czytelna: język, niezależnie od swojej nieoszacowanej wartości dla kultury, postrzegany z różnych punktów widzenia ujawnia coraz to nowe fragmenty swojej struktury z ich wzajemnym uwikłaniem, nie tracąc jednak spójności i tożsamości9.

Czy koncepcja paradygmatu jest więc potrzebna? Lingwiście nie wypada oczywiście zabierać głosu w imieniu wszystkich nauk, jednak na podstawie pobieżnej analizy użyć tego terminu w literaturze $\operatorname{lingw}$ is tycznej i w praktyce komunikacyjnej można stwierdzić, że kryje się pod nim pojęcie bliższe i intuicyjnie jaśniejsze, a mianowicie te oria10. Teoriami realizowanymi przez różne nurty i szkoły badawcze były lub są językoznawstwo historyczno-porównawcze, strukturalizm, generatywizm i nauki kognitywne. Mimo wewnętrznych podziałów i niespójności każda z nich zawierała jakieś arbitralne jądro pojęciowe i aparat metodologiczny, każda miała swoich oddanych zwolenników, każda wreszcie świadoma była swoich możliwości i ograniczeń. Mówienie w tym kontekście o zmianie paradygmatu, polegającej na obaleniu teorii wcześniejszej, tak jak ma to miejsce w naukach przyrodniczych, prowadzi do nieporozumien. Nieporozumieniem jest bowiem twierdzenie, iż lingwistyka historyczno-porównawcza została „obalona”, ponieważ język jest strukturą, w której istnieje prymat całości nad elementami składowymi, a następnie strukturalizm został „obalony” przez generatywizm, ponieważ język jest wrodzonym mechanizmem generowania i rozpoznawania zdań gramatycznych. Okres przedparadygmatyczny jest więc po prostu okresem przednaukowym albo przedteoretycznym, a przedmiot badania, czyli język, opisywany być może wieloma teoriami jednocześnie w sposób różny, ale niesprzeczny. O konkurencyjności teorii w sensie darwinistyczno

8 W wersji oryginalnej praca rozpoczyna się rzeczownikiem „History... ”, co zapewne jest świadomym zabiegiem autora, promującego myślenie kategoriami naukowych praw rozwoju historycznego o charakterze teleologicznym.

9 Można dodać, że z tych samych względów w nauce o informacji stosuje się pojęcie klasyfikacji fasetowej (polichierarchicznej).

10 Określenia pokrewne, takie jak klimat badawczy lub moda intelektualna, należą do sfery języka potocznego, a nie naukowego. 
-ewolucyjnym można mówić jedynie w obrębie jednego podejścia badawczego (por. Magee, 1998, 61-71; Chmielewski, 2003, 171-178).

W tym miejscu warto odwołać się do słów filozofa, który wydaje się pokazywać problem rozdrobnienia metod nauki w innym świetle. W pracy Wszechświat otwarty Karla R. Poppera (1996, 68-70) czytamy:

Nasze teorie naukowe pojmuję jako ludzkie twory — sieci, które wymyślamy po to, aby pochwycić w nie świat. [...] Nigdy jednak nie będą one instrumentami spełniającymi bez zarzutu swój cel. Są racjonalnymi sieciami, które zrobiliśmy sami i których nie należy mylić z zupełną reprezentacją realnego świata we wszystkich jego aspektach; nie wolno nam tak sądzić nawet wtedy, gdy teorie te są bardzo udane, ani nawet wtedy, gdy wydają się stanowić znakomite przybliżenie do rzeczywistości. [...] Metoda nauki polega na naszych próbach opisania świata za pomocą prostych teorii: teorie złożone mogą okazać się niesprawdzalne, nawet jeżeli są prawdziwe. Nauka to sztuka systematycznych uproszczeń - sztuka określania tego, co możemy z korzyścią dla siebie pominąć.

Popper zdaje się więc usprawiedliwiać ten pozornie chaotyczny sposób traktowania języka przez naukę. Potwierdza też prawdę znaną nauce, mówiąc nam, że u p r o s z czenie jest ceną uogólnienia. Określenia w rodzaju „pełnego opisu” czy „ostatecznego wyjaśnienia” należy więc włożyć między bajki albo potraktować jako formę autoreklamy konkretnego naukowca, szkoły lub ośrodka. Korzystając z popperiańskich metafor, należałoby powiedzieć, że żadna „racjonalna sieć” nie zdoła nigdy uchwycić wszystkich aspektów języka, a jedynie ich fragmenty — funkcje, struktury, podsystemy, mechanizmy generowania i/lub przyswajania, sposoby oddziaływania itd. Dlatego właśnie, mimo pozornej niespójności, podejście fasetowe i wynikający z niego synkretyzm metodologiczny okazały się w ciągu ostatnich dziesięcioleci poznawczo najefektywniejsze.

Podsumowując te uwagi, można więc przyjąć, że językoznawstwo ma charakter naukowy, ale stopień rygoryzmu i precyzji jego twierdzeń oraz spójność jego teorii nie są tak wysokie, jak w dyscyplinach przyrodoznawczych. Nie wynika to jednak z rozdrobnienia i niedojrzałości naukowej środowiska lingwistycznego, ale ze złożoności przedmiotu badań i jego głębokiego uwikłania w tkankę społeczną, historię naturalną, anatomię człowieka, cybernetykę i rozliczne dziedziny aplikacyjne. Naturalnym tego efektem jest opisana wyżej wielość podejść do materii językowej, określana jako podejście fasetowe, oraz konieczność zapożyczania od innych dyscyplin rozwiązań metodologicznych.

\section{Metodologia - jej znaczenie i wybrane pojęcia}

Uzasadnieniem celowości refleksji nad metodologią językoznawstwa i jej związkami z empirycznymi metodami przyrodoznawstwa jest podzielane przez większość naukowców przekonanie, iż dobra metoda badawcza stanowi niezbędny warunek skutecznego poznawczo postępowania, gwarantujący wiarygodność uzyskanego wyniku. Poniżej przedstawię kilka istotnych dla metodologii rozróżnień pojęciowych i terminologicznych, wskażę także na znaczenie i potrzebę ilościowych badań języka. 
Na wstępie należy rozróżnić między dwoma bliskimi, ale jednak różnymi pojęciami, a więc teorią i metodą. Przez metodę badań należy rozumieć zbiór założeń teoretycznych oraz ciąg praktycznych procedur (lub ich opisów) prowadzących do sformułowania sądów o języku. Teoria lingwistyczna jest natomiast spójnym i niesprzecznym zbiorem weryfikowalnych sądów na temat języka. Teoria może prowadzić do stworzenia własnych, specyficznych procedur badawczych (na przykład strukturalistyczna metoda komutacyjna, służąca do segmentacji ciągu mowy oraz identyfikacji jednostek), jednak brak jest koniecznego związku między teorią a stosowanymi metodami. Oznacza to na przykład, że mimo silnie antyempirycystycznej postawy Noama Chomsky'ego, korpusy teksów, które jego zdaniem nie miały użyteczności poznawczej, można z powodzeniem wykorzystywać do weryfikacji lub trenowania modeli komputerowych, służących do automatycznej analizy tekstu, stworzonych w oparciu o teorię inspirowaną generatywizmem. Jak płynne jest powyższe rozróżnienie świadczyć może porównanie tytułów i zawartości prac Jacka Fisiaka (Wstęp do wspótczesnych teorii lingwistycznych — Fisiak 1985) oraz Brigitte Bartschat (Methoden der Spraschwissenschaft - Bartschat, 1996). Chociaż obie zawierają uporządkowane chronologicznie teoretyczne opisy praktycznie tych samych szkół lingwistycznych XIX i XX wieku, niemiecka autorka użyła terminu „metoda”, a nie „teoria”.

Kolejna opozycja, tym razem pozorna, dotyczy autonomii metodologicznej językoznawstwa. Gdy mowa o źródłach metod badawczych lingwistyki, można mianowicie wskazać dwa podejścia: zdaniem jednych metodologia powinna być tworzona specjalnie dla jej potrzeb, zdaniem drugich może, a nawet powinna być zapożyczana od innych nauk, w szczególności społecznych i przyrodniczych. Zjawisko to określam jako dualizm metodologiczny. Karol Janicki pisze na ten temat, co następuje:

One of the perennial methodological problems concerns the dichotomy of view on the uniformity of research methods for all empirical sciences. Roughly, the dichotomy involves two conflicting claims. One is that all empirical sciences should employ the same research methods, and what is significant, the methods should be those of the natural sciences. The other claim is that the social sciences, as opposed to the natural sciences, should seek their own methodological principles, as dictated primarily by their research object. The latter claim evolves from the fact that at least some natural science methods have been found by many researches to be inapplicable to the study of man. It follows that a student of man must develop his own working procedures in addition to, and partly in place of, those employed by the natural scientist. (Janicki, 1982)

Trudno powiedzieć, dlaczego „ludzka natura” przedmiotu badań miałaby wymuszać tworzenie nowych metod w językoznawstwie, skoro nie czynią tego inne nauki. Na przykład medycyna czerpie obficie z biologii, a socjologia stosuje od lat metody statystyczne. Istotniejszą kwestią jest jednak pozorny, jak wyżej wspomniano, charakter powyższej opozycji. Każde badanie, nie tylko lingwistyczne, wymaga przecież pewnej ramy teoretycznej, która determinuje to, co w danym wypadku uważa się za istotne, a więc podlegające obserwacji i analizie. Rama teoretyczna pozwala wskazać jednostki relewantne lub ich najważniejsze cechy, określa sposób ich delimitacji. Przyjmując na przykład, iż konieczna jest segmentacja ciągu mowy na jednostki 
odpowiadające leksemom, należy odwołać się do podstaw leksykologii, zastosować definicję leksemu, a także wskazać na te jego cechy, które powinny podlegać kwantyfikacji lub parametryzacji. ${ }^{11}$ Jednak po zgromadzeniu danych i nadaniu im postaci liczbowej, możliwości teorii lingwistycznej wyczerpują się. Konieczne jest wtedy odwołanie się do ogólnie stosowanych metod statystyki, pozwalających między innymi na określenie parametrów pozycyjnych zbioru danych (średnia i rozrzut cechy), korelacji lub innych związków elementów (matryca podobieństwa jednostek leksykalnych, łączliwość jednostek, mapa podobieństwa tekstów), a jeżeli uwzględniana była zmienna czasu, także charakterystyk dynamicznych opisujących oscylacje wartości parametrów w czasie (na podstawie tekstów generuje się tzw. szeregi leksykalne). Powrót do pojęć stosowanej teorii lingwistycznej powinien nastąpić dopiero na etapie interpretacji, kiedy przetworzone dane liczbowe zostają przełożone na treść hipotez ujętych w system zdań.

W praktyce na metodę badawczą w pełnej postaci składają się więc dwie składowe: specyficzna dla danej dyscypliny lub teorii (może to być metoda filologiczna, metoda rekonstrukcji wewnętrznej, metoda strukturalistyczna w fonologii itd.) oraz ogólna, oparta na rachunku prawdopodobieństwa, statystyce matematycznej i różnych metodach numerycznych. O niespójności metodologicznej można mówić dopiero wówczas, gdy dochodzi do wymieszania teorii od siebie odległych, posługujących się niekompatybilnym słownictwem i aparatem pojęciowym (przykładem takiego działania może być wyjaśnianie kategoriami fizyki teoretycznej struktury dzieła literackiego). W tym miejscu można także odwołać się do bliskich ludzkiej wrażliwości kategorii estetyki, określając czyste metodologicznie rodzaje uzasadnień jako „eleganckie”, przeciwstawiając je podejściom eklektycznym.

Kolejną istotną dla metodologii lingwistyki parą pojęć jest klasyczna opozycja indukcjonizmu i dedukcjonizmu. Ten pierwszy kojarzyć należy z podejściem empirycznym i korpusowym, które ma charakter aposterioryczny. Oznacza to w praktyce, że formułowanie wniosków przez lingwistę musi zostać poprzedzone zgromadzeniem danych, ich przetworzeniem i analizą. Przy podejściu dedukcjonistycznym hipotezy formułowane są apriorycznie, ale w oparciu o racjonalne przesłanki. Doświadczenie, czyli praca na korpusie, może być tylko ich weryfikacją. ${ }^{12}$

Przedstawione tu strategie mają charakter modelowy i w czystej postaci nie mogą być użyte w badaniach lingwistycznych. Podejście indukcjonistyczne zakłada bowiem możliwość rejestracji faktów stricte doświadczalnych, odartych z jakiejkolwiek otoczki teoretycznej. Jednak wbrew poglądom Koła wiedeńskiego nauka takich faktów nie zna, ponieważ obserwacja oparta na biernej percepcji w postępowaniu naukowym nie istnieje. Natomiast rejestracja (pamięciowa, techniczna) jakiejkolwiek obserwacji zakłada jej teoretyczną racjonalizację. Racjonalizacja procesu poznawczego występuje zarówno przed obserwacją (zebraniem danych, odwołaniem się do korpusu lub ankiety), ma wtedy charakter aprioryczny, jak i po niej, kiedy ma charakter

11 Przez kwantyfikację należy rozumieć systematyczne i racjonalne zastępowanie cech elementów języka liczbami. Parametryzacja oznacza natomiast tworzenie liczbowych reprezentacji bardziej złożonych pojęć. Można więc kwantyfikować długość każdej jednostki językowej z osobna, parametryzować można natomiast zbiór jednostek (korpus, tekst), wykorzystując do tego celu wcześniejszą kwantyfikację (Pawłowski, 1977, 72-107).

12 Definicje użytych w powyższym akapicie pojęć, historię ich rozwoju oraz krytyczną dyskusję na ich temat znaleźć można między innymi w pracy Filozofia a nauka (Cackowski, 1987). 
aposterioryczny. Odnosząc się do racjonalizacji apriorycznej, można zauważyć, że korzystanie z korpusu tekstów musi założyć istnienie przedmiotu obserwacji, a więc jakichś jed nostek językowych — zdań, leksemów, frazeologizmów, głosek, fonemów, klas gramatycznych itd. — zdefiniowanych przed badaniem, a nie po nim. Można nieco przewrotnie dodać, że nawet korpusy określane przez ich twórców jako reprezentatywne dla całości języka, zawierające ustalone procentowo komponenty stylistyczne, są realizacją wcześniejszych teoretycznych założeń co do samego pojęcia reprezentatywności. ${ }^{13}$ Racjonalizacja aposterioryczna jest natomiast etapem oczywistym, polega na przetworzeniu danych obserwacyjnych, włączając w to dane pochodzące z introspekcji samego badacza, i dokonuje się zawsze w oparciu o określoną teorię, czyli jej pojęcia i prawa.

Stosowalność metody czysto dedukcyjnej w lingwistyce wydaje się także bardzo ograniczona z uwagi na ogromną presję wszechobecnych danych eksperymentalnych. Dedukcja jako metoda postępowania nauk formalnych (matematyki, logiki) może się sprawdzić jedynie w teorii języków sztucznych i/lub konstruowanych, niewymagającej empirycznych weryfikacji. Są to jednak peryferie lingwistyki, a nie główny nurt jej zainteresowań. Jeżeli teoria mówi coś o rzeczywistym przedmiocie badań, a w lingwistyce tak się właśnie dzieje, konfrontacja jej sądów z rzeczywistością jest nieunikniona, nawet wówczas, gdy autorami owych sądów są największe autorytety nauki instytucjonalnej.

Kompromisowym rozwiązaniem sporu między podejściami indukcyjnym i dedukcyjnym jest falsyfikacjonizm. Za Karlem Popperem można przyjać, że $\mathrm{w}$ naukach przyrodniczych, ale także w lingwistyce, weryfikacja nie jest dowodem prawdziwości hipotezy, co więcej dowodu takiego dostarczyć się nie da. Można jedynie wykazać, że na danym etapie rozwoju teorii pewna hipoteza jest najlepszą z możliwych, a więc spośród wielu teorii konkurujących ma relatywnie największą moc eksplanacyjną. Nawet bowiem jeżeli hipotezę zweryfikuje się pozytywnie $n$ razy, zawsze mogą pojawić się nowe dane lub techniki, dzięki którym weryfikacja $n+1$ da wynik negatywny. Natomiast obalenie hipotezy jest podstawą jej definitywnego odrzucenia (por. Magee, 1998, 19-37; Chmielewski, 2003, 62-65; Amsterdamski, 1987, 591).

Problemem metodologii językoznawstwa, pojawiającym się także podczas formułowania hipotez, jest fakt, iż język jest tworem dynamicznym, zmieniającym się w czasie i przestrzeni, co praktycznie wyklucza formułowanie sądów deterministycznych (por. Sambor, 1972, 13-14). Takim sądem byłoby na przykład stwierdzenie średnia długość wyrazu w polszczyźnie, wyrażona w morfemach, jest dokładnie taka, a nie inna, a to dlatego, że nie jest jasne, jak definiuje się polszczyznę, nie wiadomo też, jak rozumie się pojęcie wyrazu. ${ }^{14} \mathrm{O}$ dokładnych wartościach parametrów można mówić jedynie przy indukcji zupełnej, jednak wtedy zakres wnioskowania jest z góry ograniczony.

Powszechnie akceptowanym wyjściem z tej sytuacji jest rezygnacja z deterministycznej wizji języka, polegająca na zastąpieniu kategorycznych sądów ogólnych są-

13 Mieści się w nim między innymi wiedza o wewnętrznym stylistycznym rozczłonkowaniu języka oraz pojęcie stabilności cech próby ze względu na jej długość.

14 Pojęcia „polszczyzny w ogóle” albo „polszczyzny ogólnej” są konstrukcjami teoretycznymi, które nie wytrzymują weryfikacji empirycznej. 
dami statystycznymi o zasięgu ograniczonym w czasie i przestrzeni. Sądy takie mają następującą postać: $z$ prawdopodobieństwem nie mniejszym niż p oczekiwać mo $\dot{z}-$ na, iż dana relacja zachodzić będzie $w$ określonym czasie na typologicznie podobnym materiale, przy czym wartość p powinna być dostatecznie wysoka (Sambor, 1972, 12-18; Hammerl, Sambor, 1990, 185-194). Próg tolerancji uznany w naukach społecznych i w lingwistyce za wiarygodny wynosi 95 procent. Uznanie, iz jedynymi możliwymi twierdzeniami lingwistyki są sądy statystyczne o zasięgu ograniczonym w czasie i przestrzeni nie jest jednak dowodem postawy minimalistycznej badaczy języka i słabości całej dyscypliny. Świadczy jedynie o tym, że natura przedmiotu badań, ujmowanego w całym swoim bogactwie i złożoności, wyklucza inne podejścia.

Skoro przedmiot badań musi pozostać niedookreślony, źródeł wiarygodności teoriotwórczego dyskursu językoznawczego powinno się szukać w metodologii badań ilościowych, wymuszającej rygor procedur badawczych przez pełne korzystanie z narzędzi statystyki i rachunku prawdopodobieństwa oraz metod numerycznych. Podejście takie, o ile stosowane jest w sposób konsekwentny, pozwala na naturalne przechodzenie od obserwacji jednostkowych do uogólnień, a następnie ujmowanie tychże w formę praw naukowych (por. Hammerl, Sambor, 1990; Köhler et al., 2005; Kułacka, 2008).

Argumenty przemawiające za stosowalnością w nauce o języku metod ilościowych są następujące:

— język jest prymarnie systemem znaków, a sekundarnie elementów innego typu 15 , posiadającym na wszystkich poziomach analizy dys k retną reprezentację dyskursywnego kontinuum (Pawłowski, 1977, 76-83),

- możliwe jest przeprowadzenie poznawczo uzasadnionej segmentacji i kwantyfikacji danych językowych na poziomie tekstu i systemu,

— kwantyfikacji podlega każda cecha języka, także jego warstwa semantyczna (por. Osgood et al., 1957),

- możliwe i sensowne jest przetwarzanie numeryczne danych liczbowych reprezentujących teksty i/lub system, prowadzące do budowania modeli matematycznych (funkcyjnych, probabilistycznych),

— możliwa jest językoznawcza interpretacja wyników liczbowych i/lub modeli matematycznych, które uzyskano, przekształcając za pomocą narzędzi numerycznych pierwotne dane obserwacyjne,

- w swoim normalnym funkcjonowaniu system językowy podlega działaniu me chanizmu samoregulacji, który powoduje, iż utrzymywana jest równowaga między nakładem energii wkładanej w proces komunikowania a jego efektywnością (zasada ta tłumaczy działanie statystycznych praw języka - por. Köhler et al., 2005; Kułacka, 2008),

— mechanizm samoregulacji języka jest pochodną mechanizmu ekonomii wysiłku, występującego także w systemach biologicznych i społecznych,

— skutkiem działania procesu samoregulacji jest kształtowanie formy języka na wszystkich poziomach analizy, obserwowane zarówno w synchronii, jak i w diachronii (na przykład skracanie często używanych form językowych, określane jako nieregularny rozwój spowodowany frekwencją, por. Mańczak, 1988).

15 Chodzi o elementy składowe znaków (na przykład morfemy) oraz konstrukcje wieloznakowe (na przykład zdania lub frazy). 
Konkluzję powyższych rozważań można ująć w stwierdzeniu, iż za niezbędne kryterium naukowości językoznawstwa należy uznać — oprócz spójnej, niesprzecznej i efektywnej poznawczo teorii języka - stosowanie metodologii opartej na ilościowych, weryfikowalnych i powtarzalnych procedurach badawczych. Mimo pewnej dozy redukcjonizmu poznawczego (w badaniach lingwistycznych nie sposób bowiem uwzględnić wszystkich zmiennych), ilościowe podejście wprowadza naukowy rygor, podnosi moc eksplanacyjną hipotez, stwarza też możliwość odkrywania praw ogólnych o charakterze interdyscyplinarnym, co sprawia, iż przynajmniej w pewnych obszarach lingwistyka odchodzi od idiografii, przesuwając się w kierunku nauk nomotetycznych (por. Cackowski, 1987; Krajewski, 1998).

\section{Bibliografia}

Altmann, G., 1995, Statistik für Linguisten, Trier: WVT.

Amsterdamski, S., 1987, Rozwój nauki, [w:] Z. Cackowski (red.), Filozofia a nauka. Zarys encyklopedyczny, Wrocław, Warszawa, Kraków: Ossolineum, 589-598.

Bajor, K., 1970, Zastosowanie metod statystyki językoznawczej do analizy zasobu stownikowego podręczników języka rosyjskiego, Łódź: Uniwersytet Łódzki.

Bartmiński, J., 1988, Kryteria ilościowe w badaniu stereotypów językowych, „Biuletyn Polskiego Towarzystwa Językoznawczego" 41, 91-104.

Bartmiński, J. (red.), 2004 [1999], Językowy obraz świata, Lublin: Wydawnictwo Uniwersytetu Marii Curie-Skłodowskiej.

Bartschat, B., 1996, Methoden der Sprachwissenschaft, Berlin: Erich Schmidt Verlag.

Butler, Ch. S., 1985, Statistics in linguistics, Oxford: Blackwell.

Cackowski, Z. (red.), 1987, Filozofia a nauka: zarys encyklopedyczny, Wrocław, Warszawa, Kraków: Ossolineum.

Chmielewski, A., 2003, Filozofia Poppera. Analiza krytyczna, Wrocław: Wydawnictwo Uniwersytetu Wrocławskiego.

Cockiewicz, W., Śliwiński, W., 1982, O pewnej metodzie badań ilościowych frazeologii wspótczesnej polszczyzny mówionej w telewizji, [w:] A. M. Lewicki (red.), Statość i zmienność zwiazków frazeologicznych, Lublin: Wydawnictwo UMCS, 137-162.

Czekanowski, J., 1913, Zarys metod statystycznych w zastosowaniu do antropologii, Warszawa: Towarzystwo Naukowe Warszawskie.

Dębowski, Ł., 2001, Tagowanie i dezambiguacja morfosyntaktyczna. Przeglad metod i oprogramowania, Warszawa, seria IPI PAN Reports 934, listopad 2001.

Fisiak, J., 1985, Wstęp do wspólczesnych teorii lingwistycznych, Warszawa: Wydawnictwa Szkolne i Pedagogiczne.

Furdal, A., 1990, Jezzkoznawstwo otwarte, Wrocław, Warszawa, Kraków: Ossolineum.

Gruszczyński, L., 2001, Kwestionariusze w socjologii, Katowice: Wydawnictwa Uniwersytetu Śląskiego.

Hajduk, Z., 2001, Ogólna metodologia nauk, Lublin: Redakcja Wydawnicza Katolickiego Uniwersytetu Lubelskiego.

Hajnicz, E., Kupść, A., 2001, Przeglad analizatorów morfologicznych dla języka polskiego, Prace IPI PAN 937, grudzień 2001.

Hammerl, R., Sambor, J., 1990, Statystyka dla językoznawców, Warszawa: Wydawnictwo Naukowe PWN.

Hammerl, R., Sambor, J., 1993, O statystycznych prawach językowych, Warszawa: Zakład Semiotyki Logicznej Uniwersytetu Warszawskiego.

Janicki, K., 1982, The foreigner's language in a sociolinguistic perspective, Poznań: Wydawnictwo Uniwersytetu im. Adama Mickiewicza. 
Kamiński, S., 1998, Nauka i metoda. Pojęcie nauki i klasyfikacja nauk, Lublin: Towarzystwo naukowe Katolickiego Uniwersytetu Lubelskiego.

Köhler, R., Altmann, G., Piotrowski, R. (red.), 2005, Quantitative Linguistik/Quantitative Linguistics. Ein Internationales Handbuch/An International Handbook, Berlin, New York: Walter de Gruyter.

Kopczyńska, Z., Pszczołowska, L., 1959, Użyteczność metod statystycznych w leksykografii, stylistyce i wersyfikacji, Sprawozdania z Prac Naukowych Wydziału Nauk Społecznych PAN 3/1,104-107.

Krajewski, W., 1998, Prawa nauki, Warszawa: Książka i Wiedza.

Kuhn, T., 1968, Struktura rewolucji naukowych, tł. H. Ostromęcka, Warszawa: Wydawnictwo Naukowe PWN.

Kułacka, A., 2008, Statystyczne prawa językowe. Przyklad prawa Menzeratha-Altmanna $w$ sktadni języków polskiego $i$ angielskiego, praca doktorska przygotowana na Uniwersytecie Wrocławskim pod kierunkiem prof. Adama Pawłowskiego (w przygotowaniu do publikacji).

Lewandowska-Tomaszczyk, B. (red.), 2005, Podstawy językoznawstwa korpusowego, Łódź: Wydawnictwo Uniwersytetu Łódzkiego.

Magee, B., 1998, Popper, tł. Paweł Dziliński, Warszawa: Prószyński i Ska.

Mańczak, W., 1988, O nieregularnym rozwoju fonetycznym spowodowanym frekwencja, „Biuletyn PTJ” 41, 105-111.

Manning, Ch. D., Schütze, H., 2000, Foundations of statistical natural language processing, Cambridge, Mass. etc.: MIT Press.

Muller, Ch., 1973, Initiation aux méthodes de la statistique linguistique, Paris: Hachette.

Muller, Ch., 1977, Principes et methodes de statistique lexicale, Paris: Classiques Hachette.

Nowak, S., 2007, Metodologia badań spolecznych, Warszawa: Wydawnictwo Naukowe PWN.

Osgood, Ch. E., 1964, Semantic differential technique in the comparative study of cultures, "American Anthropologist" 66(3), 171-200.

Osgood, Ch. E., Suci, G. J., Tannenbaum, P. H., 1957, The Measurement of Meaning, Urbana: University of Illinois Press.

Pamuła, S., 1996, Metoda analizy zawartości prasy i jej zastosowanie w wybranych tygodnikach, Częstochowa: Wydawnictwo WSP.

Pawłowski, A., 2001, Metody kwantytatywne w sekwencyjnej analizie tekstu, Warszawa: Katedra Lingwistyki Formalnej Uniwersytetu Warszawskiego.

Pawłowski, T., 1977, Pojęcia i metody współczesnej humanistyki, Wrocław, Warszawa, Kraków: Ossolineum.

Pawłowski, T., 1978, Tworzenie pojęć $i$ definiowanie $w$ naukach humanistycznych, Warszawa: Wydawnictwo Naukowe PWN.

Piasecki, M., Szpakowicz, S., Broda, B. 2009, A Wordnet from the Ground Up, Wrocław: Oficyna Wydawnicza Politechniki Wrocławskiej.

Pieter, J., 1967, Ogólna metodologia pracy naukowej, Wrocław, Warszawa, Kraków: Ossolineum.

Pisarek, W., 1983, Analiza zawartości prasy, Kraków: Ośrodek Badań Prasoznawczych.

Pogonowski, J., Zgółka, T. (red.), 1996, Przyczynki do metodologii lingwistyki, Poznań: Wydawnictwo Naukowe Uniwersytetu im. Adama Mickiewicza w Poznaniu.

Popper, K. R., 1996, Wszechświat otwarty. Argument na rzecz indeterminizmu, tł. Adam Chmielewski, Kraków: Znak.

Sambor, J., 1972, Stowa i liczby. Zagadnienia językoznawstwa statystycznego, Wrocław, Warszawa, Kraków: Ossolineum.

Snider, J. G., Osgood, Ch. E. (ed.), 1969, Semantic Differential Technique: a sourcebook, Chicago: Aldine Publishing Company. 
Stalmaszczyk, P. (red.), 2006, Metodologie językoznawstwa, Łódź: Wydawnictwo Uniwersytetu Łódzkiego.

Stalmaszczyk, P. (red.), 2008, Metodologie językoznawstwa. Wspótczesne tendencje i kontrowersje, Kraków: Lexis.

Steczkowski, J., 1995, Metoda reprezentacyjna w badaniach zjawisk ekonomiczno-spolecznych, Warszawa, Kraków: Wydawnictwo Naukowe PWN.

Svartvik, J., 1992, Corpus Linguistics comes of Age, [in:] J. Svartvik (ed.), Directions in corpus linguistics: proceedings of Nobel Symposium 82, Stockholm, 4-8 August 1991, Berlin etc.: Mouton de Gruyter, 7-13.

Szymura, J., 1985, Bronistawa Malinowskiego „etnograficzna teoria jezzyka”, [w:] Flis, M., Paluch, A. (red.), Antropologia spoleczna Bronistawa Malinowskiego, Warszawa: Wydawnictwo Naukowe PWN, 177-205.

Wąsik, Z. (red.), 1996, Heteronomie języka, Wrocław: Wydawnictwo Uniwersytetu Wroclawskiego.

Woods, A., Fletcher, P., Hughes, A., 1986, Statistics in language studies, Cambridge: Cambridge University Press.

Zgółkowa, H., 1987, Ilościowa charakterystyka wspótczesnej polszczyzny, Poznań: Wydawnictwo Uniwersytetu im. Adama Mickiewicza. 